\title{
Macroeconomic Policies And Economic Growth: The Case Of Costa Rica
}

\author{
Yu Hsing, (E-mail: yhsing@ selu.edu), Southeastern Louisiana University \\ Aristides Baraya, (E-mail: abaraya@ selu.edu), Southeastern Louisiana University \\ Michael C. Budden, (E-mail: mbudden@ @elu.edu), Southeastern Louisiana University
}

\begin{abstract}
Applying the well-known GARCH/ARCH (Engle, 1982, 2001) model, we find that real output in Costa Rica is positively affected by real M2 money, the expected inflation rate, and the U.S. output and negatively influenced by the depreciation of the colon. Consistent with the Barro-Ricardo (1989) hypothesis, deficit spending does not affect real output. Therefore, the Costa Rican government may need to pursue a balanced budget and maintain the stability of the colon because the costs of currency depreciation outweigh the benefits.
\end{abstract}

\section{INTRODUCTION}

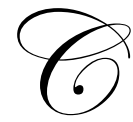

osta Rica has relatively high GDP per capita, an educated population, a stable democratic government, and strong social programs. It was well known for its tourism, national forestry, and producing and exporting coffee, bananas, sugar, and pineapples. In recent years, the relative importance of these farm products has declined due to low prices. Intel, DSC Communications, Proctor and Gamble, Motorola, Abbott Laboratories, Sawtek, Baxter Healthcare, Acer, and other foreign businesses have replaced the agricultural sector as the engine of economic growth (Vogel, 1998). Its free trade zones attract many firms and provide employment and business opportunities for many Costa Ricans.

The Costa Rican government has pursued fiscal and structural reforms. Since the 1990s, the government attempted to balance the budget, cut government size and number of public employees, enhanced the equity and efficiency of the tax system, eliminated 30 minor taxes, phased out tax incentives and exemptions, raised taxes on gasoline and diesel by 15 percentage points, doubled tax audits of large taxpayers, extended the reduction of import duties on consumer and intermediate goods, strengthened supervision and monitoring of the securities exchange and pension funds to reduce irregularities and ensure actuarial viability, passed legislation to make the central bank an independent agency, initiated deposit insurance, decreased investments by government-run enterprises, privatized public enterprises in electricity, water and phone, and raised rates of government-run utilities, among others. But, still the government yielded to interest groups by adopting the concept of the "governing by consensus," which suggests that the government would not take actions if interest groups were so opposed (Daremblum, 1991; Jul et al., 1998).

King (2003) reported that the U.S. and the five Central American countries including Costa Rica, El Salvador, Guatemala, Honduras, and Nicaragua were negotiating a Central America Free Trade Agreement (CAFTA) in order to expand NAFTA further south. The amount of trade between the U.S. and the five countries was over US\$20 billion in 2001. The U.S. would like these countries to lower import tariffs and open up the markets to U.S. products and services such as movies, drugs, music, insurance, financial services, software, etc. These countries would like to export meat, plants, tropical fruits, and additional farm products to the U.S. One of the challenging trade issues is the request by these countries to export sugar to the U.S. Approval appears imminent, and such will hurt the sugar industry in Louisiana and several other states. 
Aayau (2003) expressed concerns about the proposed trade agreement. Several key items are not subject to reduced tariffs, thus protecting them from foreign competition and providing them continual protection through charging higher prices. Some clauses require the five countries to meet U.S. labor and environmental standards. It would cost their private industry billions to comply with the U.S. standards. These five countries are required to form a common market in that all of them will have the same rules and standards. It could harm the more advanced nations and force them to lower their standards.

Concerns exist about several macroeconomic issues in Costa Rica. Its annual inflation rate reached a high of $90.2 \%$ in 1982 and has since declined in the long run to $9.2 \%$ in 2002, which is still relatively high compared with many industrialized countries. The very high inflation rate in 1982 was partly attributable to the very high growth rate of the M2 money supply of $87.3 \%$ in 1981 . The money supply grew at an annual rate of $20.9 \%$ in 2002 . The very high inflation rate and the rapid growth of money supply in the early 1980s were also associated with the exchange rate depreciation from 8.57 colones per U.S. dollar in 1980 to 21.76 in 1981 and 34.71 in 1982. The rapid depreciation of the colon raised import prices, fueled domestic inflation, and increased the money supply to accommodate the increased costs of goods and services and cost of living. In recent years, the colon continued to depreciate from 91.58 in 1990 to 359.82 in 2002. Because of continued depreciation of the colon, it is anticipated that import prices would rise to give pressure to the domestic price level. Another factor that triggered the 1982 rapid inflation was the large government deficit from $4.4 \%$ as a percent of GDP in 1978 to $8.1 \%$ in 1980. Although the government made substantial efforts to reduce deficits to $2.4 \%$ in 1981 and $0.96 \%$ in 1982 , it was too late to stop rapid inflation. Since 1997, the government deficit/GDP ratio has remained below 3.0\%, which is regarded as a healthy fiscal policy. However, government debt is a continuing concern. In 1981, Costa Rica became the first country in Latin America that could not pay the interest on its international debt and had to ask for relief. Government debt continued to rise and almost doubled during 1997 - 2001. Interest expense was almost $30 \%$ of government revenues, and about $42 \%$ of the government budget in 2001 was borrowed. More detailed analysis can be found in Rennhack et al., 2001).

This paper attempts to examine whether and how monetary policy, fiscal policy, the exchange rate policy and other relevant factors would affect real GDP in Costa Rica and has several different aspects. The theoretical model is based on an extended IS-LM model in that real GDP is derived from the equilibrium condition in the goods market and the money market. Exogenous variables such as world output are considered. The ARCH/GARCH (Engle, 1982, 2001) model is applied to test whether error variance may be a function of past squared errors and past variances.

\section{LITERATURE SURVEY}

There are several major articles studying the impacts of monetary policy, fiscal policy, the exchange rate policy, and other variables on real output or other related macroeconomic variables. Mishkin (1995) indicated that an increase in the money supply would affect real output positively through the interest rate channel, the exchange rate channel, the wealth effect, Tobin's q theory of business investment spending, and the credit channel (the bank lending channel and the balance-sheet channel). Taylor (1995) emphasized the importance of the interest rate channel whereas Bernanke and Gertler (1995) stressed the significance of the credit channel. Kuttner and Mosser (2002) summarized more recent studies on the monetary policy transmission mechanism.

Hoelscher (1983) examined the impact of U.S. federal deficits and debt on nominal interest rates. Based on different sample periods and definitions, he showed that increased federal government borrowing does not increase interest rates significantly. Barth, Iden and Russek $(1984,1985)$ found that empirical findings are very sensitive to measurements of government debt or deficit, samples, types of nominal interest rates, and independent variables specified in the model. They reported that increased deficit and debt cause interest rates to rise, reduce investment and consumption expenditures, reduce the money demand, and shift aggregate expenditures downward. Al-Saji (1991) examined the determinants of real interest rates by considering expected inflation rates, the money supply, and government spending and deficit. He showed that government spending and deficit have a significant positive impact on real interest rates and that the coefficients for expected inflation rates and the money supply are insignificant.

Vamvoukas (2002) attempted to test the relationship between the interest rate and budget deficit based on the Keynesian model and the Barro-Ricardo (1989) hypothesis. The results show a joint or bilateral causality between 
interest rates and budget deficit. Hence, the findings are consistent with the Keynesian model. Cebula (2003) indicated that there exists a long-run stable relationship between interest rates and budget deficits.

In the well-known Barro-Ricardo hypothesis, Barro (1989) indicated that deficit-financed government spending would have a neutral effect on real output in the long run because households would figure out there would be a tax increase in the future to pay for the government debt. However, Blanchard (1985) and Bernheim (1989) argued that deficit-financed spending would have some positive impact on real output because more time horizons may be considered in evaluating government tax measures.

Edwards (1985) studied the effect of devaluations on real output based on a sample of 12 developing countries. He considered money policy, fiscal policy, the change in the terms of trade, and currency devaluations. He reported that currency devaluations have a negative impact in the short run, and a positive impact after the first year, and have a neutral effect in the long run. Bahmani-Oskooee and Meteza (2003) reviewed and surveyed many studies on the impacts of currency devaluations. They indicated that devaluations would raise net export and shift aggregate demand to the right and would raise import prices and costs and shift aggregate supply to the left. Theoretically, domestic prices would rise, and output may or may not increase depending upon the relative shifts of aggregate demand and aggregate supply. They indicated that impacts of devaluations vary with countries, specifications of the model, and techniques of regression analysis.

\section{THE MODEL}

Suppose that consumption spending (C) is a function of disposable income, that investment spending (I) is affected by the real interest rate, that net exports (NX) are influenced by the real exchange rate and world output, and that real money demand (RM) is a determined by real GDP and the nominal interest rate. The equilibrium in the goods market and the money market can be expressed as

$$
Y=C(Y-T X)+I(i)+G V+N X[E X, Y W]
$$

$R M=L(Y, R)$

where

$$
\begin{array}{ll}
\mathrm{Y} & =\text { real GDP, } \\
\mathrm{TX} & =\text { real government tax revenues, } \\
\mathrm{i} & =\text { the real interest rate, } \\
\mathrm{GV} & =\text { real government spending, } \\
\mathrm{EX} & =\text { the real exchange rate, } \\
\mathrm{YW} & =\text { world output, } \\
\mathrm{RM} & =\text { real M2, } \\
\mathrm{i} & =\mathrm{R}-\pi^{\mathrm{e}}, \\
\mathrm{R} & =\text { the nominal interest rate, and } \\
\pi^{\mathrm{e}} & =\text { the expected inflation rate. }
\end{array}
$$

Suppose that equations (1) and (2) have continuous partial derivatives and that the Jacobian determinant is nonzero, the implicit functions for equilibrium $\mathrm{Y}, \bar{Y}$ can be expressed as

$$
\bar{Y}=f\left(R M, G V, T X, E X, \pi^{e}, Y W\right)
$$

The sign of RM should be negative because an increase in RM would shift the LM curve to the right, reduce the interest rate, and raise real output. The sign of TX is expected to be negative as an increase in TX would shift the IS curve to the left, reduce real output, and cause the interest rate to decline. An increase in GV is expected to shift the IS curve to the right and raise the interest rate. As mentioned in the literature survey, the effect of budget deficit (GV - 
TX) on the interest rate or output is inconclusive (Hoelscher (1983; Barth, Iden and Russek, 1984, 1985; Al-Saji, 1991; Vamvoukas 2002; Cebular, 2003; Barro, 1989; Blanchard, 1985; and Bernheim. 1989).

An increase in the real exchange rate means a depreciation of the colon and is expected to increase net exports, which will in turn shift the IS to the right. However, currency depreciation would raise import and domestic prices and reduce real wealth and income. Thus, the net impact of currency depreciation may be unclear (Edwards, 1985; Bahmani-Oskooee and Meteza, 2003). A higher expected inflation rate reduces the real interest rate and encourages investment spending, which expects to shift the IS curve to the right and raise real output. It should be noted that a higher expected inflation rate may harm output due to some negative effects such as the menu cost, the shoeleather cost, inconvenience, resource misallocations, confusion, etc. (Chang and Hsing, 1999). The impact of world output (YW) on the equilibrium output is expected to be positive because an increased world output would stimulate the export sector and help raise real output .

that

The effects on a change in RM or EX on $\bar{Y}$ can be examined by the comparative-static analysis. Suppose

$$
L_{R}<0, C_{Y}>0, L_{Y}>0, I_{R}<0, \text { and } N X_{E X}>0
$$

The endogenous-variable Jacobian is:

$$
|J|=L_{R}\left(1-C_{Y}\right)+L_{Y} I_{R}<0
$$

It can be demonstrated that the impact of a change in $\mathrm{RM}$ on $\bar{Y}$ is:

$$
\frac{\partial \bar{Y}}{\partial R M}=\frac{\left|J_{R M}\right|}{|J|}=\frac{I_{R}}{L_{R}\left(1-C_{Y}\right)+L_{Y} I_{R}}>0 .
$$

It can also be shown that the impact of a change in $\mathrm{EX}$ on $\bar{Y}$ is

$$
\frac{\partial \bar{Y}}{\partial E X}=\frac{\left|J_{E X}\right|}{|J|}=\frac{L_{R} N X_{E X}}{L_{R}\left(1-C_{Y}\right)+L_{Y} I_{R}}>0 .
$$

\section{EMPIRICAL RESULTS}

The sample consists of annual data ranging from 1971 to 2001. The data for some of the variables for 2002 is not available. Quarterly data is not used due to lack of adequate observations. All the data were obtained from the International Financial Statistics published by the International Financial Statistics. EX is the colones per U.S.dollar. Thus, an increase in EX is a depreciation, and vice versa. Real GDP in the U.S. in billions of the 1996 dollar is used as a proxy for YW due to the influential role that the U.S. plays in the world economy. Y, DE, and RM are measured in billions of colones. We use the current inflation rate for the expected inflation rate as the information on inflation is available on the Internet once it is released by the government.

We test unit roots and cointegration due to the time series sample. According to the augmented Dickey-Fuller (ADF) test, all the variables have unit roots in levels and are stationary in difference. The trace test statistic is estimated to be 99.59 compared with the critical value of 76.07 at the $1 \%$ level. Hence, all the variables have a longterm stable relationship. 
Table 1 presents the estimated regression and statistics. We first applied the $\operatorname{GARCH}(1,1)$ process to determine if error variance would be a function of past squared error and past error variance. We found that the coefficient for the past error variance is insignificant. Thus, the ARCH process is reported. As shown, the coefficient for $\mathrm{ARCH}(1)$ is significant at the $1 \%$ level, suggesting that error variance is a function of the past squared error.

As shown in Table 1 , the adjusted $\mathrm{R}^{2}$ has a value of $98.8 \%$, suggesting that the explanatory power of the right-hand side variables is pretty high. The coefficient of RM, EX, $\pi^{\mathrm{e}}$, and $\mathrm{YW}$ are significant at the $1 \%$ level, and the coefficient of DE is insignificant at the 10\% level. Specifically, if real M2 increases by 1 billion, real GDP is expected to rise by 0.75 billion. It is interesting to note that an increase in government deficit spending would not affect real GDP significantly. The finding is consistent with the Barro-Ricardo hypothesis (Barro, 1989) that deficit-financed government spending would have a neutral effect in the long run. The negative sign of the real exchange rate suggests that a depreciation of the colon would harm real output mainly because negative impacts of the depreciation such as domestic inflation and decline in real income and wealth would outweigh its positive effects of increased exports. An increase in the expected inflation rate would help real output mainly because of a lower real interest rate that would stimulate business investments. The influence of the U.S. economy on Costa Rica is strong. If U.S. real GDP declines by US $\$ 1$ billion, real GDP in Costa Rica will drop by CRC $\$ 0.28$ billion.

\section{SUMMARY AND CONCLUSIONS}

In this study, we have examined the impacts of several major macroeconomic variables on real GDP for Costa Rica. These independent variables include real M2, real government deficit spending, the real exchange rate, the expected inflation rate, and the U.S. output as a proxy for the world economic condition. The theoretical model and comparative-static analyses are presented. The GARCH/ARCH model is applied in empirical model. Major findings can be summarized below. Real output in Costa Rica is positively associated with real M2, the expected inflation rate, and U.S. output and negatively affected by the depreciation of the colon. Changes in real government deficit spending would not affect real output statistically.

There are several policy implications. First, the economic condition of the U.S. is quite important for Costa Rica and other countries and represents the external factor that is beyond the control of the Costa Rican government. As the U.S. economy is improving in recent months, it is expected to affect the Costa Rican economy positively. Second, although the rapid depreciation of the colon in recent years has helped the export sector and tourism, its net impact on real GDP is negative. Hence, to depreciate the colon to stimulate the economy may not be an appropriate option in the long run as rising inflation and declining real income and wealth would outweigh its positive effects. Third, the government may need to pursue a more conservative fiscal policy to reduce deficit spending, reduce government size, and cut expenses to have a more efficient government. By doing so, more resources would be available for households and businesses in the private sector which arguably is more efficient than the public sector.

There may be several areas for future research. The real interest rate may be considered as an exogenous variable to influence household and business expenditures. If the data is available, the wealth variable may be considered because it would affect household consumption spending and business investment decisions. If more observations are available, the VAR model may be employed to test the simultaneous relationships among some of the variables. Fiscal policy may be measured differently by separating government spending from government tax revenues. 
Table 1: Estimated ARCH Regression for Real GDP in Costa Rica

\begin{tabular}{|c|c|c|c|c|}
\hline \multicolumn{5}{|l|}{ Dependent Variable: Y } \\
\hline \multicolumn{5}{|c|}{ Method: ML - ARCH (Marquardt) } \\
\hline \multicolumn{5}{|c|}{ Sample(adjusted): 19712001} \\
\hline \multicolumn{5}{|c|}{ Included observations: 31 after adjusting endpoints } \\
\hline \multicolumn{5}{|c|}{ Convergence achieved after 84 iterations } \\
\hline \multicolumn{5}{|c|}{ Bollerslev-Wooldrige robust standard errors \& covariance } \\
\hline \multicolumn{5}{|c|}{ Variance backcast: OFF } \\
\hline & Coefficient & Std. Error & z-Statistic & Prob. \\
\hline $\mathrm{C}$ & -11.52595 & 42.94496 & -0.268389 & 0.7884 \\
\hline RM & 0.754438 & 0.104078 & 7.248749 & 0.0000 \\
\hline $\mathrm{DE}$ & -0.208443 & 0.350793 & -0.594204 & 0.5524 \\
\hline EX & -3.257331 & 0.277499 & -11.73817 & 0.0000 \\
\hline$\pi^{\mathrm{e}}$ & 1.910606 & 0.488213 & 3.913469 & 0.0001 \\
\hline \multirow[t]{2}{*}{ YW } & 0.281983 & 0.016750 & 16.83518 & 0.0000 \\
\hline & \multicolumn{4}{|c|}{ Variance Equation } \\
\hline $\mathrm{C}$ & 1110.448 & 460.6554 & 2.410583 & 0.0159 \\
\hline ARCH(1) & 0.697499 & 0.241196 & 2.891840 & 0.0038 \\
\hline R-squared & 0.991060 & \multicolumn{2}{|c|}{ Mean dependent var } & 1558.603 \\
\hline Adjusted R-squared & 0.988339 & \multicolumn{2}{|c|}{ S.D. dependent var } & 564.9109 \\
\hline S.E. of regression & 61.00155 & \multicolumn{2}{|c|}{ Akaike info criterion } & 11.10135 \\
\hline Sum squared resid & 85587.36 & \multicolumn{2}{|c|}{ Schwarz criterion } & 11.47141 \\
\hline Log likelihood & -164.0709 & \multicolumn{2}{|c|}{ F-statistic } & 364.2515 \\
\hline Durbin-Watson stat & 1.002381 & \multicolumn{2}{|c|}{ Prob(F-statistic) } & 0.000000 \\
\hline
\end{tabular}

\section{REFERENCES}

1. Al-Saji, Amer K., "The Effect of Government Budget Deficits on Real Interest Rates: Empirical Evidence from Italy, 1960:1-1990:2," International Review of Economics and Business, Vol. 38, No. 10-11, pp. 871$878,1991$.

2. Ayau, Manuel, F., “Americas: An Unfree Trade Agreement for Central America," Wall Street Journal, Eastern Edition, p. A.9, August 9, 2003.

3. Barth, James R., George R. Iden, and Frank S. Russek, "Do Federal Deficits Really matter?" Contemporary Policy Issues, Vol. 3, No. 1, pp. 79-95, 1984-85.

4. Bahmani-Oskooee, Mohsen and Ilir Miteza, "Are Devaluations Expansionary or Contractionary: A Survey Article," Economic Issues, Vol. 8, No. 2, pp. 1-28, 2003.

5. Barth, James, R. George Iden, and Frank S. Russek, "Federal Borrowing and Short Term Interest Rates: Comment," Southern Economic Journal, Vol. 52, No. 2, pp. 554-559, 1985.

6. Barro, Robert J., "The Ricardian Approach to Budget Deficits," Journal of Economic Perspectives, Vol. 3, No. 2, pp. 37-54, 1989.

7. Basurto, Gabriela and Atish Ghosh, "The Interest Rate-Exchange Rate Nexus in Currency Crises," IMF Staff Papers, Vol. 47, No. 0, pp. 99-120, 2001.

8. Belton, Willie J. and Richard J. Cebula, "International Capital Inflows, Federal Budget Deficits, and Interest Rates, 1971-1984," Quarterly Journal of Economics and Business, Vol. 34, No. 1, pp. 3-13, 1995.

9. Bernanke, Ben S. and Mark Gertler, "Inside the Black Box: The Credit Channel and Monetary Policy Transmission," Journal of Economic Perspectives, Vol. 9, No. 4, pp. 27-28, 1995.

10. Bernheim, Douglas B., “A Neoclassical Perspectives on Budget Deficits," Journal of Economic Perspectives, Vol. 3, No. 2, pp. 55-72, 1989.

11. Blanchard, Olivier, "Debts, Deficits, and Finite Horizons," Journal of Political Economy, Vol. 93, No. 2, 223-247, 1985.

12. Bremnes, Helge, Oystein Gjerde, and Frode Soettem, "Linkages among Interest Rates in the United States, Germany and Norway,” Scandinavian Journal of Economics, Vol. 103, No. 1, pp. 127-145, 2001.

13. Cebula, Richard J., "Budget Deficits and Interest Rates in Germany," International Advances in Economic Research, Vol. 9, No. 1, pp. 64-68, 2003. 
14. Chang, Hui S. and Yu Hsing, "Impacts of Inflation on Output Growth: Test of the Feldstein versus the Fischer Hypothesis," International Review of Economics and Business, Vol. 46, No. 4, pp. 677-686, 1999.

15. Coppock, Lee and Marc Poitras, "Evaluating the Fisher Effect in Long-Term Cross-Country Averages," International Review of Economics and Finance, Vol. 9, No. 2, pp. 181-192, 2000.

16. Daremblum, Jamie, "The Americas: Costa Rica Risks Missing the Boat on Free Trade," Wall Street Journal, Eastern Edition, p. A15, December 6, 1991.

17. Dekle, Robert, Cheng Hsiao, and Siyan Wang, "Do Higher Interest Rates Appreciate Exchange Rates during Crisis?" Oxford Bulletin of Economics and Statistics, Vol. 63, No. 3, pp. 359-380, 2001.

18. Edwards, Sebastian, "Are Devaluations Contractionary?" NBER Working Paper no. 1676, 1985.

19. Engle, Robert F., "GARCH 101: The Use of ARCH/GARCH Models in Applied Econometrics," Journal of Economic Perspectives, Vol. 15, No. 4, pp. 157-168, 2001.

20. Engle, Robert F., "Autoregressive Conditional Heteroscedasticity with Estimates of the Variance of United Kingdom Inflations," Econometrica, Vol. 50, No. 4, pp. 987-1008, 1982.

21. Frantischek, F., et al., "Costa Rica: Recent Economic Developments," IMF Staff Country Report No. 98/45, 1998.

22. Gali, Jordi, "How Well Does the IS-LM Model Fit Postwar U.S. Data?" Quarterly Journal of Economics, Vol. 107, No. 2, pp. 709-738, 1992.

23. Hatemi-J, Abdulnasser and Manuchehr Irandoust, "Exchange Rates and Interest Rates: Can Their Causality Explain International Capital Mobility?” International Trade Journal, Vol. 14, No. 3, pp. 299-314, 2000.

24. Hoelscher, Gregory, "Federal Borrowing and Short Term Interest Rates," Southern Economic Journal, Vol. 50, No. 2, pp. 319-333, 1983.

25. Hsing, Yu, "Impacts of External Debt and Other Macroeconomic Policies on Output in Brazil: A VAR Approach," Revista de Analisis Economico, Vol. 18, No. 2, pp. 97-108, 2003.

26. Jul, A. M., et al., "Costa Rica: Recent Economic Developments," International Monetary Fund, 1998.

27. Junttila, Juha, "Testing an Augmented Fisher Hypothesis for a Small Open Economy: The Case of Finland," Journal of Macroeconomics, Vol. 23, No. 4, pp. 577-599, 2001.

28. King, Neil, Jr., "U.S., Central American Nations Launched Trade Talks," Wall Street Journal, Eastern Edition, p. A.9, January 9, 2003.

29. Kuttner, Kenneth N. and Patricia C. Mosser, "The Monetary Transmission Mechanism: Some Answers and Further Questions," Federal Reserve Bank of New York Economic Policy Review, Vol. 8, No. 1, pp. 15- 24, 2002.

30. MacDonald, Ronald and Jun Nagayasu, "The Long-Run Relationship between Real Exchange Rates and Real Interest Rate Differentials: A Panel Study," IMF Staff Papers, Vol. 47, No. 1, pp. 116-128, 2000.

31. Mishkin, Frederic S., "Symposium on the Monetary Transmission Mechanism," Journal of Economic Perspectives, Vol. 9, No. 4, pp. 3-10, 1995.

32. Rennhack, Robert, et al., "Costa Rica: Selected Issues," International Monetary Fund, 2001.

33. Taylor, John B., "The Monetary Transmission Mechanism: An Empirical Framework," Journal of Economic Perspectives, Vol. 9, No. 4, pp. 11-26, 1995.

34. Vamvoukas, George A., "Budget Deficits and Interest Rates in a Small Open Economy - Another Look at the Evidence: Reply,” International Economic Journal, Vol. 16, No. 2, pp. 31-36, 2002.

35. Vogel, Thomas T, Jr., "Costa Rica's Sales Pitch Lures High-Tech Giants Like Intel and Microsoft," Wall Street Journal, Eastern Edition, p. 1, April 1, 1998. 
NOTES 